\title{
Implications of Blended Learning for Learning Innovation During and After the Covid-19 Pandemic
}

\author{
Andi Lely Nurmaya. $\mathrm{G}^{1}$, Acoci ${ }^{2}$, Suardin ${ }^{3}$, Hizrayanti ${ }^{4}$, Andi Aswat Jahudin ${ }^{5}$ \\ \{andilelynurmya@yahoo.co.id $\left.{ }^{1}\right\}$
}

Primary School Teacher Education, University Muhammadiyah Buton, 93721, Indonesia ${ }^{1,2,3,4,5}$

\begin{abstract}
In primary school education, the learning process which is usually done face-toface between teachers and students in the classroom is now being replaced by an online system to implement social distance. The impact of the Covid-19 pandemic requires educators to be able to innovate in creating a learning process from a face-to-face learning process that is difficult to implement at this time. The purpose of this study was to determine the implications of blended learning during the pandemic. The object of this research is students and teachers. This research is a qualitative descriptive study. Data collection techniques using observation and interviews. Structured interviews are conducted with a list of interview questions that will be developed related literature. The results of this study indicate the achievement of student learning completeness during the learning of blended learning, student activities, student and teacher responses to the implementation of blended learning.
\end{abstract}

Keywords: Blended learning, learning innovation, covid-19

\section{Introduction}

The Minister of Education and Culture of the Republic of Indonesia issued Circular Number 4 of 2020 concerning Implementation of Education Policies in an Emergency for the Spread of COVID, in this Circular it was explained that the learning process is carried out at home through online / distance learning to provide meaningful learning experiences for students. Learning at home can be focused on life skills education, among others, regarding the Covid-19 pandemic. The implementation of appropriate learning strategies during the Covid-19 pandemic is to combine interesting learning methods or models, appropriate learning media and learning resources, and involve students in active learning to make it easier for teachers to achieve student learning goals. Teachers are required to be able to design learning strategies so that students can focus on implementing learning in school so that learning becomes meaningful. Problems with learning problems in the classroom such as boredom, not understanding the material provided, or students having fun playing on their own can be anticipated if teachers are creative in developing their learning strategies [1].

Becoming a professional teacher is a necessity that must be realized. It is appropriate as a teacher who lives in this digital age to add skills in the field of technology and be able to adapt to the times [2]. So many teachers are professional but do not have good pedagogical skills. Pedagogical abilities include the ability to organize educational learning, utilize information and communication technology for the benefit of learning and facilitate the development of the potential of students to actualize their various potentials. Therefore, the need for the ability of 
teachers to combine various learning sources, use of appropriate methods and mastery of the material is absolutely necessary [3].

During the Covid 19 pandemic, learning carried out in elementary schools also used online / distance learning through parental guidance. With online learning students have the flexibility to study time, can study anytime and anywhere. Teachers are required to choose a learning model that encourages each student to be actively involved in learning activities which are their learning experiences [4]. Sele ction of learning models used in class can affect mastery of the material being taught and student learning outcomes. The learning model carried out is by implementing blended learning or direct learning collaboration with e-learning based learning tools which aims to eliminate student boredom and improve student learning outcomes.

Some of the problems found in the online learning process during the Covid-19 pandemic, namely 1) there are still teachers who have difficulty managing learning that is focused on curriculum achievement. 2) there are still parents who have difficulty assisting children to learn. 3) limited facilities and infrastructure that can be used in online learning (online). 4) The feeling of saturation of children with online learning (online).

The blended learning model is a learning activity that combines face-to-face and online activities [5]. In its application, this learning reduces direct learning in class. the purpose of using blended learning can be formulated as follows: (1) helping students to develop better in the learning process according to their learning styles and learning preferences; (2) provide practical-realistic opportunities for teachers and students to learn independently, be useful and continue to develop and (3) increase scheduling flexibility for students, by combining the best aspects of face-to-face and online learning. Blended learning is to make students more active and independent in learning. The advantages of the blended learning model are that it can be used to convey learning material wherever and whenever, learning occurs online and offline which complement each other, learning becomes effective and efficient, increases accessibility, and learning becomes flexible and not rigid [6]. The blended learning model with the help of the google classroom application is used as a tool that functions to smoothen the teaching and learning activities of the Acehnese oral tradition material [7]. Thus, face-to-face learning in class can be collaborated with online learning using internet media, called Blended Learning. Blended Learning is a combination of the advantages of learning that is done face-to-face and virtually $[8]$.

Research also states that the blended learning model can increase student enthusiasm in learning so as to improve student learning outcomes. Research also states that the blended learning model makes students feel more satisfied when compared to only using conventional learning models [9]. Realizing the problems that students can experience in learning during the Covid-19 pandemic, the teacher always makes efforts to provide the best service. Blanded learning is one of the best solutions during the 19th pandemic in creating better education services. Despite the facts in the field there are still schools that have not been able to adapt to more modern learning. This is presumably due to the difficulty in managing learning that combines online and offline learning (blended learning). However, researchers feel this problem is very important to be investigated to determine the achievement of blanded learning learning in elementary schools. Based on these problems and previous studies, the author tries to make a study entitled "The implications of Blanded Learning on learning innovation during covid 19". 


\section{Method}

This type of research is descriptive. Descriptive research is research conducted with the aim of systematically describing the facts and characteristics of the object under study accurately. This study describes the implementation of blended learning in elementary schools. The approach used in this study is a qualitative approach. The qualitative approach is carried out based on the data and facts found in the field and the research methods used to examine the conditions of natural objects, the task of the researcher as a key instrument.

Most of the data collected are qualitative data and the analysis technique uses qualitative techniques. This technique was chosen by researchers to produce qualitative data, namely data that cannot be categorized statistically. In the use of qualitative analysis, interpreting what was found and drawing final conclusions using logic or systematic reasoning. The qualitative analysis used is an interactive analysis model, which is an analysis model that requires three components in the form of data reduction, data presentation, and conclusion / verification.

This research was conducted in the elementary school in Baubau city, the researcher chose 5 schools to study. This school was chosen because it already has complete learning facilities with smooth and fast internet network facilities, making it easier for the teaching and learning process to use blended learning. The school has never implemented a learning process using blended learning.

This research was carried out in 5 elementary schools totaling 100 people. The technique of selecting research subjects was carried out using purposive sampling type, in which the subject was specifically selected based on the research objectives. In addition, the technique of selecting research subjects is also based on several considerations, such as limited time and energy so that it is not possible to take large numbers of subjects. The data collection technique was carried out to see the activities of students during the learning process using blended learning carried out with documentation, observation, and interviews. Observations and interviews were carried out by 5 people, namely each class teacher who was sampled in the study during the learning process. Each observer observes and documents student activities from the beginning to the end of the lesson.

\section{Result and discussion}

The learning model developed in this study is the Blended Rotation learning model with the Station Rotation type. The development procedure includes:

- Preliminary Study \& Needs Analysis This activity begins with a search for references / literature regarding the results of research on the application of Blended Learning in elementary schools.

- Material Analysis Material analysis was carried out by looking at the curriculum applied in elementary schools.

- Indicator analysis was carried out to formulate objectives to be achieved in this study.

- The assessment was carried out to see the level of success of implementing blended learning in elementary schools.

Based on research data on the implications of blended learning in Baubau city elementary schools, the results obtained: 


\subsection{Completeness of learning}

Based on the results of the survey conducted, it was obtained data showing that the learning completeness of elementary school students in Baubau city had increased. Of the 5 schools in the Betoambari District of Baubau City, 100 samples were observed, there were 86 students who had an average score above the minimum completeness criteria, while the 16 students observed had an average score below the minimum completeness criteria. Based on the results of observations made, the researcher saw the value of student learning outcomes given by the teacher from the 100 samples studied by looking at the results of teacher recapitulation, the highest score obtained by students was 100 and the lowest score obtained by students was 46 . learning blended leraning was successful, classical completeness> $75 \%$. Completeness of learning outcomes is in the very good category, this is in accordance with the completeness standard, namely completeness between $80 \%-100 \%$ is in the very good category and $66 \%$ $79 \%$ is in the good category.

Blended learning requires students to be more independent in following the learning process, because students have the flexibility to obtain information and consult among fellow students and teachers outside the classroom. However, students who take blended learning with low independence will feel overwhelmed by the assignments given online. So that the advantages of blended learning such as learning flexibility, self-autonomy, and collaborative learning with peers and teachers through video do not occur in students with low independence. This results in students learning completeness to be low and not optimal.

\subsection{Student activities}

In measuring the achievement of blended learning learning, researchers distributed questionnaires to measure student activity during the learning process. Measurement of student activity during the learning process is carried out using observation sheets. The researcher distributed the observation sheet to 5 class teachers who were also observers. The results of these observations can be seen in Table 1 .

Table 1. Activity during blending learning

\begin{tabular}{lll}
\hline No & School name & Percentage (\%) \\
\hline 1 & A & $86 \%$ \\
2 & B & $82 \%$ \\
3 & C & $90 \%$ \\
4 & D & $83 \%$ \\
5 & E & $92 \%$ \\
\hline
\end{tabular}

Based on the Table 1, the researcher obtained the results of student activities during the learning process. The results of these student activities have different percentage of activity data. Based on the results of observations, school A has a percentage of $86 \%$, school B has a percentage of $82 \%$, school $\mathrm{C}$ has a percentage of $90 \%$, school D has a percentage of $83 \%$ and school E has a percentage of $92 \%$. Looking at the data obtained by researchers by comparing several schools, the results of student activity during the learning process are good but not perfect. Based on the percentage obtained, there are several aspects that need to be improved, for example there are still students who have a slow response when the teacher gives assignments during the learning process and is slow to respond to the motivation given by the teacher. 


\subsection{Student responses}

Based on the questionnaire that has been distributed to students on blended learning learning, the percentage of student responses to the first statement was obtained, namely $70 \%$ who strongly agreed and $30 \%$ agreed. This is because blended learning is being applied for the first time. Student responses about learning with blended learning are more enjoyable because the material can be accessed using smartphones, the percentage of students who choose to strongly agree is $75 \%$ and $25 \%$ disagree. Student responses to the use of time in completing assignments or discussing material in blended learning are more flexible, $40 \%$ disagree and $60 \%$ agree. The responses of students were more daring to express opinions or ask questions in learning using blended learning, as many as $60 \%$ chose to agree and $40 \%$ chose to disagree.

\subsection{Teacher's response}

Based on the results of a survey conducted by researchers by giving a questionnaire to the teacher. Some of the teachers' responses regarding blended learning are 1). Blended learning makes students more enthusiastic and interested in taking part in learning, because students are very happy and enthusiastic when invited to learn and can provide additional guidance to students through e-learning courses outside of class hours. This shows that the teacher considers blended learning as a positive innovation to be applied in the learning process. 2). Blended learning is very well applied in elementary schools because blended learning will simplify the learning process and increase the intensity of communication between students and teachers.

The results of the percentage of teacher responses indicate that the application of blended learning is very good and increases the enthusiasm and independence of students in learning. The two teachers strongly agree with the online discussion statement giving opportunities for students who are less brave to ask questions in class to submit questions or problems through the e-learning course, this shows that the teacher really understands the character of the students.

\section{Conclusion}

Based on the results of the research that has been done, the following conclusions can be drawn. First, the average student learning completeness through the application of the blended learning learning model increases. The application of the blende learning model requires students to be more independent in following the learni ihng process, but students who have low learning independence will feel burdened by the assignments given online. Second, student activities in participating in learning using the high blended learning model, however, there are still students who are still slow to respond to orders given by the teacher. Third, there are still respondents who do not agree with the application of the blended learning model due to various problems including inadequate supporting facilities. Fourth, the teacher's response shows that the application of blended learning is very good and increases the enthusiasm and independence of students in learning. 


\section{Acknowledgment}

On this occasion the researchers would like to express their deepest gratitude to the leaders of the Buton Muhammadiyah University who have provided assistance so that this research can be carried out. The author also expresses his deepest gratitude to all those who have helped in the implementation of this research and hopefully this research can be a reference for other researchers.

\section{References}

[1] O. Widyaningsih, C. B. Yudha, and D. C. Nugraheny, "PENGEMBANGAN MODEL BLENDED LEARNING," pp. 143-156.

[2] M. T. Hidayat, T. Junaidi, and M. Yakob, "Pengembangan Model Pembelajaran Blended Learning dalam Meningkatkan Pemahaman Siswa Terhadap Tradisi Lisan Aceh,” vol. 25, no. 3, pp. 401-410, 2020.

[3] I. G. Ayu, A. Manik, and A. H. Simamora, "Pengembangan Pembelajaran Blended Pada Mata Kuliah Ahara Yoga Semester II di IHDN Denpasar," vol. 8, pp. 1-15, 2020.

[4] N. Nunung, "Jupendik: Jurnal Pendidikan Jupendik: Jurnal Pendidikan," Meningkat. Kebiasaan Membaca Mhs. Melalui Penugasan Membuat Pertanyaan, vol. 4, no. 1, pp. 2016-2021, 2020.

[5] W. S. Albiladi and K. K. Alshareef, "Blended Learning in English Teaching and Learning: A Review of the Current Literature," J. Lang. Teach. Res., vol. 10, no. 2, p. 232, 2019, doi: 10.17507/jltr.1002.03.

[6] D. M. D. P. Nugraha, "Integrasi Pendidikan Karakter Dalam Penerapan Blended Learning Di Sekolah Dasar," Cetta J. Ilmu Pendidik., vol. 3, no. 3, pp. 472-484, 2020.

[7] R. S. \& L. hana Lestari, "Literasi Sains Siswa Melalui Penerapan Model Pembelajaran Blended Learning Dengan Blog,” Nat. J. Kaji. Penelit. Pendidik. ..., vol. 4, no. 2, pp. 597-604, 2020, [Online]. Available: https://journal.umtas.ac.id/index.php/naturalistic/article/view/769.

[8] K. Kunci, F. Universitas, S. Ageng, and T. Email, "DI PROGRAM STUDI PENDIDIKAN MATEMATIKA UNTIRTA Anwar Mutaqin , Indiana Marethi, dan Syamsuri A BLENDED LEARNING MODEL," pp. 134-141.

[9] W. Wahyudi, I. Anugraheni, and A. Winanto, "Pengembangan Model Blended Learning Berbasis Proyek Untuk Menunjang Kreatifitas Mahasiswa Merancang Pembelajaran Matematika Sekolah Dasar," JIPM (Jurnal Ilm. Pendidik. Mat., vol. 6, no. 2, p. 68, 2018, doi: 10.25273/jipm.v6i2.1766.

[10] M. R. Braun, P. Walton, S. B. M. Beck, and W. London, "Illustrating the relationship between the coefficient of performance and the coefficient of system performance by means of an R404 supermarket refrigeration system," Int. J. Refrig., vol. 70, pp. 225-234, 2016, doi: 10.1016/j.ijrefrig.2015.10.020.

[11] Z. Ma, H. Bao, and A. P. Roskilly, "Thermodynamic modelling and parameter determination of ejector for ejection refrigeration systems," Int. J. Refrig., vol. 75, pp. 117-128, 2017, doi: 10.1016/j.ijrefrig.2016.12.005 